\begin{tabular}{|c|c|c|}
\hline $\begin{array}{c}\text { Physiological Response of Marine } \\
\text { Organisms to Polycyclic Aromatic } \\
\text { Hydrocarbons Pollution as }\end{array}$ & $\begin{array}{c}\text { “Cercetări Marine“ } \\
\text { Issue no. 51 }\end{array}$ & $\mathbf{2 0 2 1}$ \\
$\begin{array}{c}\text { Useful Tools for Biomonitoring } \\
\text { (Diana Danilov, Valentina Coatu) }\end{array}$ & Pages 193 - 200 & \\
\hline \multicolumn{2}{|c|}{ DOI:10.55268/CM.2021.51.193 } \\
\hline
\end{tabular}

\title{
Short communication: PHYSIOLOGICAL RESPONSE OF MARINE ORGANISMS TO POLYCYCLIC AROMATIC HYDROCARBONS POLLUTION AS USEFUL TOOLS FOR BIOMONITORING
}

\author{
Diana Danilov, Valentina Coatu
}

National Institute for Marine Research and Development "Grigore Antipa", 300 Mamaia Blvd., 900581, Constanta, Romania

E-mail:ddanilov@alpha.rmri.ro

\begin{abstract}
The continuous development of oil exploration and exploitation leads to the need to highlight the early effects of hydrocarbons, especially polycyclic aromatic hydrocarbons on marine organisms. In this regard, there are worldwide biomonitoring programs that aim to assess the effects of polycyclic aromatic hydrocarbons.

The physiological response of marine organisms is investigated both at functionally (reproductive, respiratory, cardiovascular and neurological disorders), tissular, cellular and molecular levels (histopathological evaluation, DNA damage, cytochrome P4501A, ethoxy resorufin-O-deethylase (EROD)). This paper reviews the changes induced by polycyclic aromatic hydrocarbons in marine organisms and their potential to be used as suitable biomarkers to assess the health of aquatic ecosystems.
\end{abstract}

Key-Words: biomonitoring, physiological response, polycyclic aromatic hydrocarbons, marine organisms, sea water

\section{AIMS AND BACKGROUND}

Millions of tons of oil are spilled in aquatic environments every decade, and this oil has the potential to greatly impact marine populations. Spilled oil may sink using a diffusion process or as bulky fractions or may be driven coastward. The continuous development of oil exploration and exploitation leads to the need to highlight the early effects of hydrocarbons, especially polycyclic aromatic hydrocarbons on marine organisms. Therefore, the assessment of the consequences of oil pollution in the Black Sea, especially in its coastal waters, is an important issue for the ecological status of the marine ecosystem. 


\section{RESULTS AND DISCUSSION}

In order to perform this evaluation, the literature has been studied and the advantages and disadvantages of using PAHs-induced physiological responses in marine organisms have been analyzed. Polycyclic aromatic hydrocarbons (PAHs) are a class of organic compounds containing two or more fused benzene rings with various structural configurations (Prabhu and Phale, 2003), where the rings could be in linear, angular, or clustered arrangements (Lundestedt, 2003). PAHs are lipophilic, have low vapor pressure and low water solubility, as well as high melting and boiling points (Skupinska et al., 2004).

Concentrations of PAHs in the aquatic environment are generally highest in sediment, intermediate in biota and lowest in the water column (Canadian Council of Ministers of the Environment (CCME) 1999, 2008). They accumulate in sediments because they tend to be absorbed by the particulate matter that settle at the bottom of aquatic ecosystems (Juhasz and Naidu, 2000; Perelo, 2010) and are often encountered in more significant concentrations in water bodies close to point sources of contamination (Juhasz and Naidu, 2000). When dissolved in the aquatic environment, PAHs can have the ability to bioaccumulate, bio magnify and can disrupt normal physiological functions to living organisms and ecosystems.

One of the most relevant considerations for bioaccumulation of PAHs in aquatic species is the amount of accumulated PAHs that is efficiently metabolized. For species that have the capacity to efficiently metabolize PAHs, they may accumulate large amounts of PAHs compounds, exhibit effects, but not contain measurable levels of the parent compounds, therefore simply measurement of PAHs levels is not relevant for estimating the pollution level. Mutagenic metabolites may however be formed, which may be more toxic than the parent compounds (Meador, 2008).

PAHs have great potential to bind to cellular proteins and DNA, often generating toxic effects. The resulting biochemical disruption and cell damage can lead to mutations, developmental malformations, tumors, and cancer (Kim et al., 2013). They can act as endocrine disruptors (ED) by mimicking or antagonizing the action of hormones that occur naturally, thereby impacting the regulation of vital life processes, including development, growth, metabolism, and reproduction (Pittinger et al., 1987; Hellou et al., 2006; Roldán-Wong et al., 2020; Pulster et al., 2019).

The absorption, distribution and toxicity of PAHs depend on several factors, including the species, route of exposure and physicochemical characteristics (CCME 1999; Ramesh et al., 2004).

Biomonitoring or biological monitoring can be defined as the systematic use of biological responses to assess changes in the environment. The 
physiological response of marine organisms is investigated both at functionally, tissular, cellular and molecular levels. Immediately as a chemical enters the body of an organism, physiological and biochemical responses are triggered. The organism could show resistance to these aggressors or could be poisoned. Within these responses, irreversible biochemical changes are the most critical in the body of organisms. Biochemical parameters used as biomarkers are those involved in metabolism pathways or cell functions.

Globally, many studies have examined the effects of PAHs on aquatic organisms (Varanasi et al., 1989; Harvey, 1997; Beasley and Kneale, 2002; Grotte et al., 2005; Hellou et al., 2006; Hjorth et al., 2007; Petersen et al., 2008).

To assess the polycyclic aromatic hydrocarbons (PAHs), on the marine ecosystem a suite of biomarkers is being extensively used worldwide. These biomarkers are being used to evaluate exposure of various species of sentinel marine organisms (mussels, clams, oysters, snails, fishes, etc.) to and the effect of various contaminants using different molecular approaches [biochemical assays, enzyme linked immuno-sorbent assays (ELISA), spectrophotometric, fluorometric measurement, differential pulsed polarography, liquid chromatography, atomic absorption spectrometry].

Biochemical and physiological parameters are used as biomarkers for contaminants and could be applied to evaluate environmental stress and its effects on aquatic organisms.

A biomarker can be defined as „the measurements of body fluids, cells, or tissues that indicate in biochemical or cellular terms the presence of contaminants or the magnitude of the host response,, (Bodin et al., 2004). Biomarkers can be any measurable biomolecules that provide early warning signs of an individual imbalance resulting from exposure to a xenobiotic (Martyniuk et al., 2019; Colin et al., 2016).

Biomarkers at the biochemical level can provide information on the qualitative and quantitative relationships between pollutant exposure and biological responses, and some of them can predict responses at higher levels of biological organization (Hyne and Maher, 2003; Seabra Pereira et al., 2014). Such early warnings of marine pollution are extremely important, as early detection will allow corrective measures to be undertaken, avoiding irreversible effects on the entire ecosystem.

Among biomarkers associated with exposure to PAHs, cytochrome P4501A enzyme induction (EROD activity), lysosomal stability, DNA integrity, liver histopathology received special attention for biomonitoring of ecotoxicological impact of PAHs. Also, studies reflect that the oil pollution of marine environment induces multiplicative stress in marine organisms and is accompanied with the generation of ROS (reactive oxygen species). The most 
used biomarkers for oxidative stress are superoxide dismutase (SOD), catalase (CAT), peroxidase (PER), and glutathione reductase (GR).

Antioxidant enzymes are known as adequate biomarkers for oxidative stress induced by many unfavorable factors. Antioxidant enzyme activities in various tissues and organs of aquatic organisms and their changes are good biomarkers for the organism status in the unfavorable living conditions, and they are used successfully as tools for biomonitoring.

Histologic biomarkers have been extensively used in fish to detect and monitor environmental pollution (Rabitto et al., 2005; Mela et al., 2007). Melano-macrophage centers are pigment-containing cells found only in fish, amphibian, and reptiles (Arciuli et al., 2015). Previous studies have shown that these centers increase in size or frequency in conditions of environmental stress and are considered as reliable biomarkers for water chemical pollution and fish health status (Agius and Roberts, 2003).

Biomarkers are influenced by natural environmental factors such as temperature, salinity, oxygen tension, trophic status as well as size, age, and reproductive condition of the sentinel organisms (Hagger et al., 2006; Holmstrup et al., 2010). It is necessary to establish the range of normal values in sentinel species. In consequence, the use of biomarkers involves the necessity of a better knowledge of their seasonal and natural variability.

Biomarkers of environmental contamination by PAHs in fish seem to vary with species, habitat and environment and are often contradictory (Aguilar et al., 2020). Therefore, they need to be species and region-specific to be efficient, especially to detect an impact on species with restricted geographic distribution (Aguilar et al., 2020).

Due to their filter-feeding nature and low enzyme activities, mussels accumulate hydrophobic pollutants in their tissues at considerably high levels so, local mussels give information about the pollution status of a certain site. On the other hand, there was no clear relationship found between the enzyme levels (ethoxy resorufin-O-deethylase, glutathione S-transferase, glutathione reductase) and the pollutant concentrations in mussels. In consequence, integrated biomarker responses were calculated to interpret the overall effect of pollutants (Brooks et al., 2010).

\section{CONCLUSIONS}

Monitoring the effects of environmental pollutants on the biota is important since it can demonstrate links between contamination and effects at several levels of biological organization. The use of biomarkers measured at the molecular and cellular level is of great importance as sensitive 'early warning' tools for biological effect measurement in environmental quality assessment. The use of biomarkers involves the necessity of a better knowledge of their seasonal and natural variability. 
The choice of organism used for biomonitoring is very important. For instance, biomarkers of environmental contamination by PAHs in fish need to be species and region-specific to be efficient. Integrated biomarker responses may be useful to interpret the overall effect of pollutants.

\section{REFERENCES}

Aguilar L., Dzul-Caamal R., Rendón-von Osten J., da Cruz AL. (2020), Effects of polycyclic aromatic hydrocarbons in Gambusia Yucatana, an endemic fish from Yucatán Peninsula, Mexico, Polycyclic Aromatic Compounds, https://doi.org/10.1080/10406638.2020.1755322

Agius C., Roberts R.J., (2003), Melano-macrophage centers and their role in fish pathology. Journal of Fish Diseases 26:499-509, University of Idaho, Hagerman, ID 83332, USA, https://doi.org/10.1046/j.13652761.2003.00485.X

Arciuli M., Brunetti A., Fiocco D., Zacchino V., Centoducati G., Aloi A., Tommasi R., Santeramo A., De Nitto E., Gallone A. (2015), A multidisciplinary study of the extracutaneous pigment system of European sea bass (Dicentrarchus labrax L.). A possible relationship between kidney disease and dopa oxidase activity level. Fish and Shellfish Immunology 42(1):184-192. https://doi.org/10.1016/j.fsi.2014.10.031

Beasley G., Knale P., (2002), Reviewing the impact of metals and PAHs on macroinvertebrates in urban watercourses.

https://doi.org/10.1191/0309133302pp334ra

Bodin N., Burgeot T., Stanisiere JY., Bocquene G., Menard D., Minier C., Boutet I., Amat A., Cherel Y., Budzinski H. (2004), Seasonal variations of a battery of biomarkers and physiological indices for the mussel Mytilus galloprovincialis transplanted into the northwest Mediterranean Sea, Comparative Biochemistry and Physiology Part C: Toxicology \& Pharmacology, 138(4):411-427.

https://doi.org/10.1016/j.cca.2004.04.009

Brooks S., Harman C., Zaldibar B., Izagirre U., Glette T., Marigómez I. (2010), Integrated biomarker assessment of the effects exerted by treated produced water from an onshore natural gas processing plant in the North Sea on the mussel Mytilus edulis, Marine Pollution Bulletin, 62(2):327339. https://doi.org/10.1016/j.marpolbul.2010.10.007

Canadian Council of Ministers of the Environment (CCME) (1999). A protocol for the derivation of ecological effects-based and human healthbased soil quality criteria for contaminated sites, Ottawa. CCME subcommittee on Environmental quality criteria for contaminated sites, Environment Canada, Canadian Council of Ministers of the Environment, 123 Main St., Suite 360, info@ccme.ca 
Carls M., Meador J., (2009), A Perspective on the Toxicity of Petrogenic PAHs to Developing Fish Embryos Related to Environmental Chemistry. https://doi.org/10.1080/10807030903304708

Colin N., Porte C., Fernandes D., Barata C., Padrós F., Carrassón M., Monroy M., Cano-Rocabayera O., de Sostoa A., Piña B., Maceda Veiga A. (2016), Ecological relevance of biomarkers in monitoring studies of macro-invertebrates and fish in Mediterranean rivers, Science of The Total Environment, 540:307-323.

https://doi.org/10.1016/j.scitotenv.2015.06.099

Grotte M., Schuurmann G., Altenburger R. (2005), Modeling photo induced algal toxicity of polycyclic aromatic hydrocarbons, Environmental Science \& Technology. https://doi.org/10.1021/es048310v

Hagger J.A., Jones M.B., Leonard D.R.P., Owen R., Galloway T.S., (2006), Biomarkers and integrated environmental risk assessment: are there more questions than answers? Integrated Environmental Assessment and Management, 2(4): 312-329. https://doi.org/10.1002/ieam.5630020403

Harvey R.G., (1997), Polycyclic aromatic hydrocarbons: Chemistry and Carcinogenicity. In: Neilson AH (ed) Cambridge Monographs on Cancer Research. Wiley, New York, NY, pp 667-670.

Hellou J., Leonard J., Collier TK., Ariese F., (2006), Assessing PAH exposure in feral finfish from the Northwest Atlantic. Marine Pollution Bulletin, 52(4): 433-441. https://doi.org/10.1016/j.marpolbul.2005.11.012

Hyne R.V., Maher W.A., (2003), Invertebrate biomarkers: links to toxicosis that predict population decline. Ecotoxicology and Environmental Safety 54(3):366-374. https://doi.org/10.1016/S0147-6513(02)00119-7

Holmstrup M., Bindesbøl AM., Oostingh GJ., Duschl A., Scheil V., Köhler HR., Loureiro S., Soares AMVM., Ferreira ALG., Kienle C., Gerhardt A., Laskowski R., Kramarz PE., Bayley M., Svendsen C., Spurgeon DJ., (2010), Interactions between effects of environmental chemicals and natural stressors: A review, Science of The Total Environment, 408(18):3746-3762. https://doi.org/10.1016/j.scitotenv.2009.10.067

Hjorth M., Vester J., Henriksen P., Forbes V., Dahllof I., (2007), Functional and structural responses of marine planktonic food web to pyrene contamination. Marine Ecology Progress Series, 338:21-31. doi:10.3354/meps338021

Juhasz A., Naidu R., (2000), Bioremediation of high molecular weight polycyclic aromatic hydrocarbons: a review of the microbial degradation of benzo[a]pyrene.

https://doi.org/10.1016/S0964-8305(00)00052-4 
Kim K.H., Jahan SA., Kabir E., Brown R.J.C., (2013), A review of airborne polycyclic aromatic hydrocarbons (PAHs) and their human health effects. Environment International, 60:71-80. https://doi.org/10.1016/j.envint.2013.07.019

Lundestedt S., (2003), Analysis of PAHs and their transformation products in contaminated soil and remedial processes. Dissertation, Umea University, Faculty of Science and Technology, Chemistry, https://www.researchgate.net/publication/265100739_Analysis_of_PA Hs_and_their_transformation_products_in_contaminated_soil_and_re medial_processes.

Martyniuk C.J., Feswick A., Munkittrick K.R., Dreier D.A., Denslow N.D., (2019), Twenty years of transcriptomics, 17alpha-ethinylestradiol, and fish, General and Comparative Endocrinology, 286, https://doi.org/10.1016/j.ygcen.2019.113325

Meador J.P., (2008), Polycyclic Aromatic Hydrocarbons, Encyclopedia of Ecology, Editor(s): Sven Erik Jørgensen, Brian D. Fath, Academic Press, 2881-2891 pp. https://doi.org/10.1016/B978-008045405-4.00413-4

Mela M., Randi M.A.F., Ventura D.F., Carvalho C.E.V., Pelletier E., Oliveira Ribeiro C.A., (2007), Effects of dietary methylmercury on liver and kidney histology in the neotropical fish Hoplias malabaricus, Ecotoxicology and Environmental Safety, 68(3):426-435. https://doi.org/10.1016/j.ecoenv.2006.11.013

Perelo L.W., (2010), Review: In situ and bioremediation of organic pollutants in aquatic sediments, Journal of Hazardous Materials,Volume, 177:8189. https://doi.org/10.1016/j.jhazmat.2009.12.090.

Petersen D.G., Reichenberg F., Dahllof I., (2008), Phototoxicity of pyrene affects benthic algae and bacteria from the Arctic. Environmental Science \& Technology, 42: 1371-1376. https://doi.org/10.1021/es071854n

Pittinger C.A., Buikema A, L., Falkinham J.O., (1987), In-situ variations in oyster mutagenicity and tissue concentrations of polycyclic aromatic hydrocarbons, Environmental Toxicology and Chemistry, 6(1):51-60. https://doi.org/10.1002/etc.5620060107

Prabhu Y., Phale P.S., (2003), Biodegradation of Phenanthrene by Pseudomonas sp. Strain PP2: novel metabolic pathway role of biosurfactant and cell surface hydrophobicity in Hydrocarbon assimilation, Applied Microbiology and Biotechnology, 61:342-351. DOI: $10.1007 / \mathrm{s} 00253-002-1218-y$ 
Pulster E.L., Gracia A., Armenteros M., Carr BE., Mrowicki J., Murawski SA., (2019), Chronic PAH exposures and associated declines in fish health indices observed for ten grouper species in the Gulf of Mexico, Science of The Total Environment, 703.

https://doi.org/10.1016/j.scitotenv.2019.135551

Rabitto I.S., Costa JA., Assis H.S., Pelletier E., Akaishi FM., Anjos A., Randi M.A.F., Oliveira Ribeiro C.A., (2005), Effects of dietary Pb (II) and tributyltin on neotropical fish, Hoplias malabaricus: histopathological and biochemical findings, Ecotoxicology and Environmental Safety, 60(2): 147-156. https://doi.org/10.1016/j.ecoenv.2004.03.002

Ramesh A., Walker SA., Hood DB., Guillien MD., Schneider K., Weyhand EH., (2004), Bioavailability and risk assessment of orally ingested polycyclic aromatic hydrocarbons, International Journal of Toxicology. https://doi.org/10.1080/10915810490517063

Roldán-Wong N.T., Kidd K.A., Ceballos-Vázquez B.P., Rivera-Camacho A.R., Arellano-Martínez M., (2020), Polycyclic aromatic hydrocarbons (PAHs) in mussels (Modiolus capax) from sites with increasing anthropogenic impact in La Paz Bay, Gulf of California, Regional Studies in Marine Science, 33. https://doi.org/10.1016/j.rsma.2019.100948

Seabra Pereira C.D., Abessa D.M., Choueri R.B., Almagro-Pastor V., Cesa A., Maranho LA., Martín-Díaz ML., Torres RJ., Gusso-Choueri PK., Almeida J.E., Cortez F.S., Mozeto A.A., Silbiger H.L., Sousa E.C., Del Valls T.A., Bainy A.C., (2014), Ecological relevance of sentinels' biomarker responses: a multi-level approach, Marine Environmental Research, 96: 118-126. https://doi.org/10.1016/j.marenvres.2013.11.002

Skupinska K., Mislewicz I., Kasprzycka-Guttman T., (2004), Polycyclic aromatic hydrocarbons: physicochemical properties, environmental appearance and impact on living organisms, Acta Poloniae Pharmaceutica, 61(3): 233-240.

DOI: https://pubmed.ncbi.nlm.nih.gov/15481250/

Varanasi U., Reichert W.L., Stein J.E., (1989), 32P-Postlabeling analysis of DNA adducts in liver of wild English sole (Parophrys vetulus) and winter flounder (Pseudopleuronectes americanus), Cancer Research, 49(5). http://cancerres.aacrjournals.org/content/49/5/1171 